Article

\title{
Risk Assessment of Potential Food Chain Threats from Edible Wild Mushrooms Collected in Forest Ecosystems with Heavy Metal Pollution in Upper Silesia, Poland
}

\author{
Marek Pająk ${ }^{1}$, Michał Gąsiorek ${ }^{2}$, Michał Jasik ${ }^{1, *}$, Wiktor Halecki ${ }^{3}{ }^{\oplus}$, Krzysztof Otremba $^{4}$ \\ and Marcin Pietrzykowski ${ }^{1}$ (1) \\ 1 Department of Forest Ecology and Silviculture, University of Agriculture in Krakow, al. 29 Listopada 46, \\ 31-425 Krakow, Poland; marek.pajak@urk.edu.pl (M.P.); marcin.pietrzykowski@urk.edu.pl (M.P.) \\ 2 Department of Soil Science and Agrophysics, University of Agriculture in Krakow, al. Mickiewicza 21, \\ 31-120 Krakow, Poland; michal.gasiorek@urk.edu.pl \\ 3 Department of Land Reclamation and Environmental Development, University of Agriculture in Krakow, \\ al. Mickiewicza 24/28, 30-059 Krakow, Poland; wiktor.halecki@urk.edu.pl \\ 4 Department of Soil Science and Reclamation, University of Life Sciences in Poznan, ul. Piatkowska 94E, \\ 60-649 Poznan, Poland; krzysztof.otremba@up.poznan.pl \\ * Correspondence: michal.jasik@urk.edu.pl
}

Received: 9 October 2020; Accepted: 21 November 2020; Published: 24 November 2020

\begin{abstract}
In this study, the contents of selected heavy metals $(\mathrm{Zn}, \mathrm{Cu}, \mathrm{Cd}, \mathrm{Pb}, \mathrm{Cr}$, and $\mathrm{Ni})$ and macroelements $(\mathrm{C}, \mathrm{N}, \mathrm{K}, \mathrm{P}, \mathrm{S}, \mathrm{Mg}, \mathrm{Na}$, and $\mathrm{Ca}$ ) were measured in wild mushrooms growing in a heavily polluted forest ecosystem in the northeastern part of the Upper Silesian Industrial Region. The research was conducted on 10 species of mushrooms belonging to three families: Boletaceae, Russulaceae, and Suillaceae. Using a spatial autoregressive model, the study showed a strong relationship between heavy metal concentrations (especially $\mathrm{Zn}, \mathrm{Pb}$, and $\mathrm{Cd}$ ) and the distance from a source of industrial pollution (a zinc smelter, Huta Miasteczko Ślaskie). The concentrations of potentially toxic metals $(\mathrm{Pb}$ and $\mathrm{Cd}$ ) in mushrooms significantly exceeded food-acceptable standards. The bioconcentration factor (BCF), calculated as the ratio between the concentration in mushroom tissues and in forest soils overall, reached the highest values for cadmium (Cd). The highest accumulation capacity for Cd was noted for Imleria badia $(\mathrm{BCF}=9.18)$, which was also the most abundant mushroom species in the study plots. In general, the established threshold values for $\mathrm{Pb}$ and $\mathrm{Cd}$ concentrations in consumer mushrooms and food products were exceeded up to almost 30-fold in the studied area. We conclude that the potential risk to human health of the toxic elements that enter the food chain through the harvesting and consumption of wild mushrooms from this region is significant.
\end{abstract}

Keywords: edible mushrooms; environmental pollution; potentially toxic elements

\section{Introduction}

Wild mushrooms are a popular delicacy collected in many countries around the world, for example, in Central, East, and South Europe and in Asia [1-4]. They are traditionally recognized as a valuable source of nutrients and as being useful in the prevention of diseases such as hypertension and cancer [5-7]. At the same time, however, they absorb heavy metals from the environment particularly easily [8,9]. Many authors have pointed out that they can thus be useful as bioindicator species [5,10-12]. According to Kalač and Svoboda [1], depending on the species, mushrooms can accumulate much 
higher concentrations of heavy metals, especially cadmium, mercury, lead, and copper, than other foods. The processes of absorption of heavy metals by mushrooms from the soil and the internal transport and accumulation of macro- and microelements in mushrooms are largely influenced by genetic and environmental factors. The main environmental factors affecting bioaccumulation of heavy metals in mushrooms include soil $\mathrm{pH}$ and texture, organic matter content, enzyme activity, and the stage of individual development [1,3]. High contents of heavy metals, such as cadmium, lead, mercury, or arsenic, in mushrooms may pose a particularly large problem and threat to human health $[1,12,13]$. According to Kalač et al. [10] and Kalač and Svoboda [1], fungi have the ability to absorb heavy metals from their substrate and accumulate them in their fruiting bodies at concentrations well above those in the substrate on which they grew. Special care should be exercised during harvesting and subsequent consumption in places where metal ores have been mined and processed for tens or even hundreds of years, leading to severe environmental contamination with these elements.

The Olkusz-Tarnowskie Góry region (Southern Poland), where zinc-lead ores have been mined and processed for centuries, is one of the more heavy-metal-contaminated areas of Central Europe, as evidenced by numerous publications [14-18]. The heavy metals introduced into that region have accumulated in the soils, as well as in plant and animal tissues [19-26].

The aims of this study were as follows:

(i) Determine the accumulation levels of selected heavy metals in forest mushrooms and assess the bioconcentration factor (BCF) in relation to soil and forest floor litter in forests under high pressure of industrial pollution, in the context of a risk assessment of the potential threats to the food chain and human health;

(ii) Determine which mushroom species and families accumulate the highest levels of heavy metals, under the studied conditions;

(iii) Describe the relationships between heavy metal contents in the mushroom tissues and the distance from the source of pollution;

(iv) Determine the possible impacts of high contents of $\mathrm{Cd}$ and $\mathrm{Zn}$ on the uptake of macroelements by the studied mushrooms.

\section{Material and Methods}

\subsection{Study Area and Material}

The material for the study consisted of the fruiting bodies of mushrooms collected in autumn of 2013 and 2014, in the Świerklaniec Forest District, Brynica sub-district, which directly borders the "Miasteczko Śląskie" zinc smelter (HCMS). The mushrooms were harvested from $100 \mathrm{~m}^{2}$ permanent research plots (Figure 1) that were arranged in a regular grid of squares $1500 \mathrm{~m}$ on a side. The completely developed and mature fruiting bodies of the investigated mushrooms were collected randomly. Each sample consisted of 10 individuals of a given species. The mushrooms were collected and determined based on experience of picker. At the same time, the surface soil layer $(0-20 \mathrm{~cm})$ and litter were sampled from all 31 plots.

The study areas are located to the northeast and east of the HCMS $\left(50^{\circ} 29^{\prime} 01^{\prime \prime}-50^{\circ} 32^{\prime} 25^{\prime \prime}\right.$ N, $18^{\circ} 57^{\prime} 10^{\prime \prime}-19^{\circ} 08^{\prime} 43^{\prime \prime} \mathrm{E}$ ), so that they are downwind for the prevailing wind direction where the largest amounts of pollutants are transferred from HCMS. The areas in question were covered with fresh mixed coniferous forest and wet mixed coniferous forest dominated by Haplic Podzols and Gleyic Podzols soils [27]. The plots are located in stands belonging to age classes II to IV [28]. Coordinates ( $\mathrm{x}$ and $\mathrm{y}$ ) were assigned to each plot. In the field, the plots were located with a Global Positioning System receiver. 


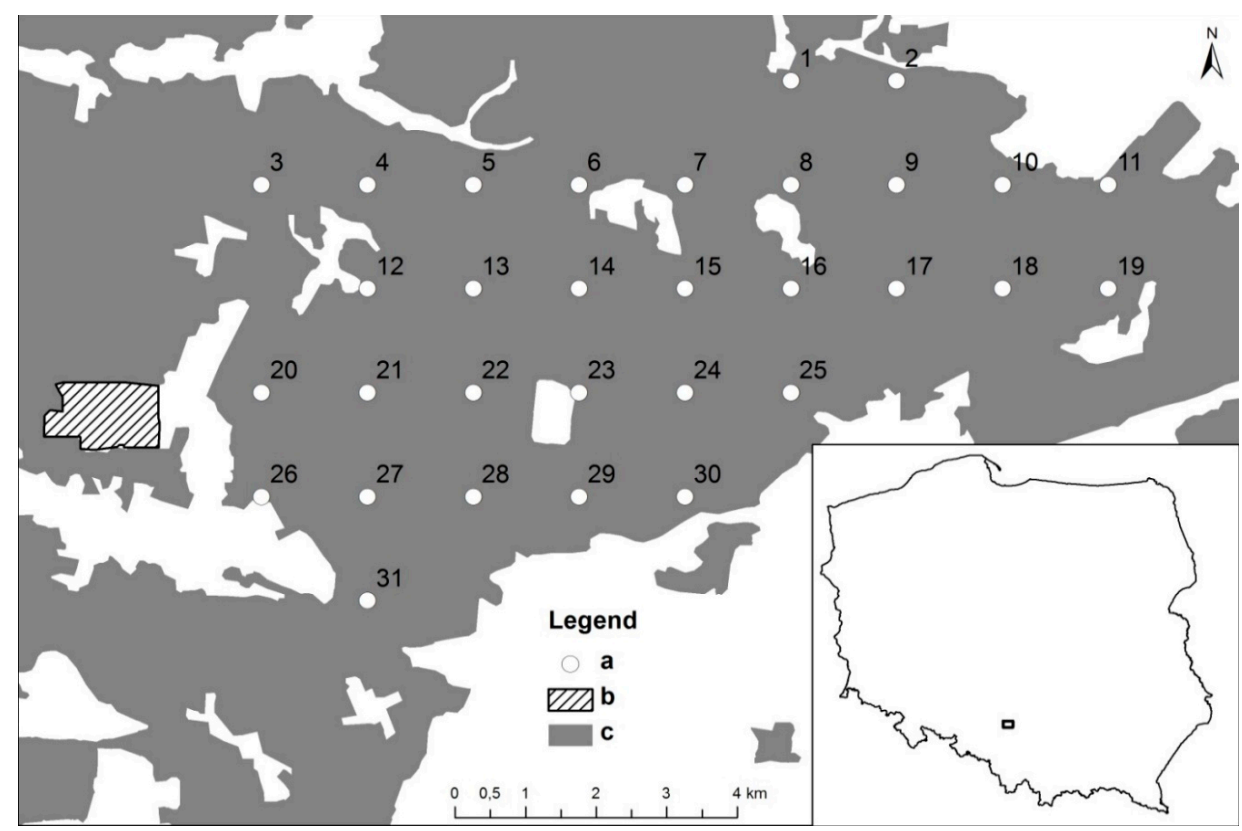

Figure 1. Location of trial plots within the Świerklaniec Forest District, the Brynica sub-district (a-trial plots, $\mathrm{b}$-zinc smelter, and c-Brynica forest sub-district).

\subsection{Laboratory Analyses}

Immediately after harvesting, sand and other impurities were thoroughly cleaned from the fruiting bodies of the mushrooms, with a plastic knife. They were then dried for several days, at room temperature, in a well-ventilated, dry, and clean place, and then transported to the laboratory. In the laboratory, the mushrooms were dried until a constant mass was obtained, in a laboratory dryer $\left(\right.$ at $\left.60^{\circ} \mathrm{C}\right)$, and crushed in a laboratory mill. Then the mushrooms were mineralized, "in wet procedure", in a mixture of concentrated nitric and perchloric acids, in the ratio 3:1. The contents of the following elements were determined in the samples prepared in this way: $\mathrm{Ca}, \mathrm{K}, \mathrm{P}, \mathrm{Mg}, \mathrm{Na}, \mathrm{Cd}, \mathrm{Cr}, \mathrm{Cu}, \mathrm{Ni}$, $\mathrm{Pb}$, and $\mathrm{Zn}$, using the ICP-AES plasma emission spectrometry technique with a Thermo Scientific iCAP 6000 Series ICP-OES spectrometer (Thermo scientific, Waltham, MA, USA). The calibration was carried out by using certified multi-element ICP-IV Merck standard solution (Merck, Darmstadt, Germany). The quality of the data was verified by using internal mushroom standards. The total organic carbon (TOC), nitrogen (N), and sulfur (S) contents were determined by using a LECO TruMac element analyzer (LECO Corporation, St. Joseph, MI, USA).

For the surface soil samples, the following parameters were determined: the texture was measured with a Fritsch GmbH Laser Particle Sizer ANALYSETTE 22 (Fritsch GmbH, Idar-Oberstein, Germany), $\mathrm{pH}$ in water; and $\mathrm{Zn}, \mathrm{Pb}$, and $\mathrm{Cd}$ contents were determined by using the a ICP-AES technique, with a Thermo Scientific iCAP 6000 Series ICP-OES spectrometer. The calibration was carried out, using certified multi-element ICP-IV Merck standard solution. The quality of the data was verified by using certified reference material CRM023-050-TraceMetals-Sandy Loam 7 (RT Corporation, Laramie, WY, USA). The contents of $\mathrm{Zn}, \mathrm{Pb}$, and $\mathrm{Cd}$ in the litter samples were determined with the same technique. In determining the contents of heavy metals in all tested materials, the precision and accuracy of the method were established. All laboratory measurements of each sample were performed at least twice.

\subsection{Statistical Analysis}

Multidimensional analysis techniques were used to analyze the concentrations of heavy metals in edible mushrooms. To identify which heavy metals were present in the highest concentrations in which mushrooms, species were grouped into families, and each metal was checked for differences in 
accumulation among families. For this purpose, a multivariate analysis of variance (MANOVA) was used. The MANOVA analysis was preceded by verifying the application conditions by examining the distribution of variables. If the variables had a non-normal distribution, they were rejected. The result obtained from the analysis was supplemented by the Hotelling pairs test with Bonferroni correction. This was graphically depicted by using canonical variate analysis (CVA). The CVA image is also presented for the most common mushroom species in the study area. The analyses were performed in the statistical program PAST ver. 3.04 [29].

The relationship between the accumulation of heavy metals in mushrooms and the distance from the source of contamination was determined by spatial autoregression. In the autoregression model, the distance from the emitter was chosen as a dependent variable, and individual heavy metal concentrations in mushrooms were treated as independent variables. The fit of the model was checked by using the ordinary least squares (OLS) technique. The best results were obtained by means of a conditional autoregressive model (CAR).

The spatial conditional autoregressive model (CAR) with correction function $C$ to the covariance matrix described the effect of distance from the emitter on the content of heavy metals in mushrooms, according to the following Equation [30]:

$$
\mathrm{C}=\left[\left(\sigma^{2} W_{i}\right) \mathrm{I}\right](\mathrm{I}-\rho \mathrm{W})^{-1}
$$

where $\mathrm{C}=$ vector of the explained spatial process, through a response variable, $\mathrm{W}=$ neighborhood weighting matrix, $\sigma^{2}=$ residual variance between observations, $\rho=$ spatial autoregression parameter reflecting the strength of the link between observations of the explained variable at different locations, and $\mathrm{I}=$ linear transformation of a dependent variable $(\mathrm{N} \times \mathrm{N}$-type matrix $)$ of an explained (dependent) variable.

All tested mushroom species were analyzed together, looking for the highest accumulations in terms of heavy metal content. On the basis of the CAR analysis, $\mathrm{Zn}, \mathrm{Cd}$, and $\mathrm{Pb}$ were selected for further statistical treatment because, of the analyzed heavy metals, only those showed significant results in the autoregressive model. The analyses were performed in Spatial Analysis in Macroecology software ver. 4.0 [30].

To indicate the extent to which mushrooms accumulate $\mathrm{Zn}, \mathrm{Cd}$, and $\mathrm{Pb}$, the bioconcentration factor (BCF) was calculated for each mushroom species [31], according to the following Equation [32,33]:

$$
\begin{gathered}
\mathrm{BCF}=\text { Bioconcentration (mushrooms)/concentration (medium) } \\
\text { Medium }=\text { soil or litter }
\end{gathered}
$$

Then, for the same elements, the relationship between their content in the soil and the litter and the content of biogenic elements in mushrooms was determined. Canonical correspondence analysis (CCA) was used for this purpose. The values with factor loads higher than 0.7 were selected. The above analysis was performed in the statistical program Canoco ver. 4.51 [34].

\section{Results}

\subsection{Soil Properties}

The basic statistics for the $\mathrm{Zn}, \mathrm{Pb}$, and $\mathrm{Cd}$ contents measured in the topsoil layer and litter are presented in Table 1 . Twenty of the 31 plots had a topsoil layer $(0-20 \mathrm{~cm})$ characterized by loamy sand, eight sandy loam, and three by clay texture. The soil $\mathrm{pH}$ ranged from 3.60 to 4.80 , with an average of 3.92 (Table 1). 
Table 1. Basic statistics of $\mathrm{pH}, \mathrm{Zn}, \mathrm{Pb}$, and $\mathrm{Cd}$ concentrations $\left(\mathrm{mg} \cdot \mathrm{kg}^{-1}\right)$ in soil and litter from study area.

\begin{tabular}{ccccc}
\hline & Mean & SD & Min & Max \\
\hline $\mathrm{pH}\left(\mathrm{H}_{2} \mathrm{O}\right)$ & 3.9 & 0.3 & 3.6 & 4.8 \\
\hline Heavy metals $\left(\mathrm{mg} \cdot \mathrm{kg}^{-1}\right)$ & \multicolumn{5}{c}{ Soils $(0-20 \mathrm{~cm})$} \\
$\mathrm{Zn}$ & 117 & 126 & 11 & 525 \\
$\mathrm{~Pb}$ & 177 & 176 & 32 & 709 \\
$\mathrm{Cd}$ & 2.9 & 2.6 & 0.4 & 11.5 \\
\hline Heavy metals $\left(\mathrm{mg}^{-} \mathrm{kg}^{-1}\right)$ & \multicolumn{5}{c}{ Litter } \\
$\mathrm{Zn}$ & 532 & 466 & 138 & 2542 \\
$\mathrm{~Pb}$ & 527 & 415 & 152 & 2108 \\
$\mathrm{Cd}$ & 15.2 & 16.9 & 3.3 & 83.0 \\
\hline
\end{tabular}

\subsection{Micro- and Macroelement Contents in Forest Mushrooms}

In total, $88(\mathrm{~N})$ mushroom samples were collected in the study area and tested in 2013 and 2014. The most common species present in the designated research plots during the study period included Imleria badia, Lactarius helvus, Russula sardonia, and Russula aeruginea (Table 2).

Table 2. Frequency and plot numbers with the collection of individual species of forest mushrooms in 2013 and 2014.

\begin{tabular}{lll}
\hline \multicolumn{1}{c}{ Mushroom (N) } & \multicolumn{1}{c}{ Plots Numbers } \\
\hline \multicolumn{1}{c}{ 2013 } \\
\hline Imleria badia (Fr.) Fr. (24) & $3 ; 4 ; 5 ; 8 ; 9 ; 11 ; 14 ; 23 ; 25 ; 29$ & \multicolumn{1}{c}{ 2014 } \\
\hline Suillus luteus (L.) Roussel (6) & $6 ; 8 ; 8 ; 9 ; 11 ; 13 ; 14 ; 15 ; 20 ; 21 ; 25 ; 28 ; 29$ \\
\hline Suillus grevillei (Klotzsch) Singer (4) & $8 ; 10 ; 11 ; 19 ; 25 ; 28$ & $6 ; 8 ; 9 ; 13 ; 22 ; 23 ; 28 ; 29$ \\
\hline Suillus bovinus (L.) Roussel (4) & $10 ; 13 ; 15 ; 26$ & $8 ; 10 ; 11 ; 19 ; 25 ; 28$ \\
\hline Lactarius deliciosus (L.) Pers. (4) & $3 ; 5 ; 25$ & $10 ; 13 ; 15 ; 26$ \\
\hline Lactarius helvus (Fr.) Fr. (18) & $15 ; 17 ; 28$ & $3 ; 5 ; 25$ \\
\hline Russula paludosa Britzelm. (6) & $3 ; 15$ & $15 ; 17 ; 28$ \\
\hline Russula claroflava Grove (4) & $11 ; 17$ & $3 ; 15$ \\
\hline Russula aeruginea Lindblad ex Fr. (8) & $19 ; 28$ & $11 ; 17$ \\
\hline Russula sardonia Fr. ss. Melz. et. Zv (12) & $8 ; 10 ; 11 ; 19 ; 25 ; 28$ & $19 ; 28$ \\
\hline
\end{tabular}

Note: $(\mathrm{N})$ number of plots in which the species of mushrooms was collected.

The concentrations of heavy metals, in decreasing order, were as follows for most of the mushroom species collected in the studied area: $\mathrm{Zn}>\mathrm{Cu}>\mathrm{Cd}>\mathrm{Pb}>\mathrm{Cr}>\mathrm{Ni}$. The highest concentrations of heavy metals among the examined mushrooms were found for $\mathrm{Zn}$ and Fe. The mean $\mathrm{Zn}$ values ranged from $79.2 \mathrm{mg} \cdot \mathrm{kg}^{-1}$ in Suillus bovinus to $451.1 \mathrm{mg} \cdot \mathrm{kg}^{-1}$ in Russula aeruginea. The mean Cd content ranged from $3.6 \mathrm{mg} \cdot \mathrm{kg}^{-1}$ in Lactarius deliciosus to $27.0 \mathrm{mg} \cdot \mathrm{kg}^{-1}$ in Imleria badia. The same species (Imleria badia) was also characterized by the highest concentration of $\mathrm{Pb}, 12.0 \mathrm{mg} \cdot \mathrm{kg}^{-1}$, and a high average $\mathrm{Cu}$ of $36.5 \mathrm{mg} \cdot \mathrm{kg}^{-1}$. Of the analyzed heavy metals, the lowest amounts in the examined mushrooms were noted for $\mathrm{Cr}$ and $\mathrm{Ni}$ (Table 3).

The concentrations of macroelements, in descending order, were as follows for most of the mushroom species collected on the research plots of the study area: $\mathrm{C}>\mathrm{N}>\mathrm{K}>\mathrm{P}>\mathrm{S}>\mathrm{Mg}>\mathrm{Na}>\mathrm{Ca}$. The average carbon content was over $400.0 \mathrm{~g} \cdot \mathrm{kg}^{-1}$ in all of the studied mushroom species and ranged from $407.0 \mathrm{~g} \cdot \mathrm{kg}^{-1}$ in Russula claroflava to $446.9 \mathrm{~g} \cdot \mathrm{kg}^{-1}$ in Suillus bovinus. Mean nitrogen ranged from $43.3 \mathrm{~g} \cdot \mathrm{kg}^{-1}$ in Suillus grevillei to $59.6 \mathrm{~g} \cdot \mathrm{kg}^{-1}$ in Imleria badia. Similar values were found for the potassium content. The P and S contents ranged on average from $4.3 \mathrm{~g} \cdot \mathrm{kg}^{-1}$ in Russula aeruginea to $7.0 \mathrm{~g} \cdot \mathrm{kg}^{-1}$ in Suillus luteus and from $2.2 \mathrm{~g} \cdot \mathrm{kg}^{-1}$ in Russula paludosa to $5.3 \mathrm{~g} \cdot \mathrm{kg}^{-1}$ in Imleria badia, respectively. 
The lowest contents among the analyzed macroelements in the examined mushrooms were noted for $\mathrm{Mg}$, Na, and $\mathrm{Ca}$ (Table 4).

Table 3. Content of heavy metals in the mushrooms of the study area.

\begin{tabular}{|c|c|c|c|c|c|c|}
\hline Element/Mushroom (N) & $\mathrm{Cd}$ & $\mathrm{Cr}$ & $\mathrm{Cu}$ & $\mathbf{N i}$ & $\mathbf{P b}$ & $\mathrm{Zn}$ \\
\hline & \multicolumn{6}{|c|}{$\left(\mathrm{mg} \cdot \mathrm{kg}^{-1}\right)$} \\
\hline Imleria badia (24) & $\begin{array}{c}27.0 \pm 17.3 \\
(7.8-84.3)\end{array}$ & $\begin{array}{l}7.0 \pm 11.0 \\
(1.3-57.0)\end{array}$ & $\begin{array}{c}36.5 \pm 24.6 \\
(2.8-90.6)\end{array}$ & $\begin{array}{l}2.2 \pm 1.6 \\
(0.5-6.5)\end{array}$ & $\begin{array}{l}12.0 \pm 24.3 \\
(1.3-102.0)\end{array}$ & $\begin{array}{c}187.4 \pm 71.6 \\
(100.4-404.0)\end{array}$ \\
\hline Suillus luteus (6) & $\begin{array}{l}12.3 \pm 7.6 \\
(6.5-20.8)\end{array}$ & $\begin{array}{l}5.0 \pm 1.1 \\
(3.9-6.1)\end{array}$ & $\begin{array}{c}20.4 \pm 19.9 \\
(0.9-39.7)\end{array}$ & $\begin{array}{l}2.1 \pm 0.9 \\
(1.1-2.9)\end{array}$ & $\begin{array}{l}4.9 \pm 1.0 \\
(3.8-5.6)\end{array}$ & $\begin{array}{l}146.9 \pm 43.7 \\
(96.6-175.6)\end{array}$ \\
\hline Suillus grevillei (4) & $\begin{array}{l}4.1 \pm 2.0 \\
(2.7-5.5)\end{array}$ & $\begin{array}{l}3.1 \pm 1.1 \\
(2.3-3.8)\end{array}$ & $\begin{array}{l}2.3 \pm 3.3 \\
(0.9-4.7)\end{array}$ & $\begin{array}{l}0.7 \pm 0.3 \\
(0.5-0.9)\end{array}$ & $\begin{array}{l}4.5 \pm 1.5 \\
(3.5-5.6)\end{array}$ & $\begin{array}{c}94.1 \pm 9.6 \\
(87.3-100.8)\end{array}$ \\
\hline Suillus bovinus (4) & $\begin{array}{l}4.3 \pm 0.8 \\
(3.8-4.9)\end{array}$ & $\begin{array}{l}2.7 \pm 0.1 \\
(2.6-2.8)\end{array}$ & $\begin{array}{l}0.2 \pm 0.0 \\
(0.1-0.3)\end{array}$ & $\begin{array}{l}1.5 \pm 0.4 \\
(1.2-1.8)\end{array}$ & $\begin{array}{l}4.2 \pm 2.2 \\
(2.7-5.7)\end{array}$ & $\begin{array}{c}79.2 \pm 8.0 \\
(73.6-84.8)\end{array}$ \\
\hline Lactarius deliciosus (4) & $\begin{array}{l}3.6 \pm 3.3 \\
(1.2-5.9)\end{array}$ & $\begin{array}{l}2.6 \pm 0.3 \\
(2.3-2.8)\end{array}$ & $\begin{array}{c}17.7 \pm 25.0 \\
(0.2-35.1)\end{array}$ & $\begin{array}{l}1.0 \pm 0.6 \\
(0.5-1.4)\end{array}$ & $\begin{array}{l}6.4 \pm 2.6 \\
(4.6-8.3)\end{array}$ & $\begin{array}{l}124.2 \pm 38.3 \\
(97.1-151.8)\end{array}$ \\
\hline Lactarius helvus (18) & $\begin{array}{c}11.5 \pm 12.5 \\
(1.4-40.9)\end{array}$ & $\begin{array}{l}4.4 \pm 2.6 \\
(2.6-9.9)\end{array}$ & $\begin{array}{c}24.8 \pm 27.8 \\
(0.2-76.3)\end{array}$ & $\begin{array}{l}1.6 \pm 0.8 \\
(0.8-2.9)\end{array}$ & $\begin{array}{c}6.7 \pm 3.9 \\
(3.0-13.8)\end{array}$ & $\begin{array}{l}147.4 \pm 48.8 \\
(81.3-219.1)\end{array}$ \\
\hline Russula paludosa (6) & $\begin{array}{c}14.4 \pm 2.7 \\
(12.7-17.5)\end{array}$ & $\begin{array}{l}3.5 \pm 1.4 \\
(1.9-4.8)\end{array}$ & $\begin{array}{c}48.1 \pm 7.0 \\
(40.3-53.8)\end{array}$ & $\begin{array}{l}1.7 \pm 1.2 \\
(0.9-3.1)\end{array}$ & $\begin{array}{c}14.0 \pm 1.5 \\
(12.8-15.6)\end{array}$ & $\begin{array}{c}129.5 \pm 25.9 \\
(110.1-158.8)\end{array}$ \\
\hline Russula claroflava (4) & $\begin{array}{l}11.1 \pm 8.9 \\
(4.8-17.4)\end{array}$ & $\begin{array}{l}10.2 \pm 6.3 \\
(5.8-14.7)\end{array}$ & $\begin{array}{c}36.8 \pm 9.3 \\
(30.3-43.4)\end{array}$ & $\begin{array}{l}2.2 \pm 0.2 \\
(2.0-2.4)\end{array}$ & $\begin{array}{l}10.5 \pm 4.5 \\
(7.4-13.7)\end{array}$ & $\begin{array}{l}302.7 \pm 128.1 \\
(212.2-393.3)\end{array}$ \\
\hline Russula aeruginea (8) & $\begin{array}{c}9.3 \pm 2.7 \\
(7.0-12.7)\end{array}$ & $\begin{array}{l}3.5 \pm 0.6 \\
(2.8-4.3)\end{array}$ & $\begin{array}{c}10.8 \pm 15.9 \\
(0.3-33.5)\end{array}$ & $\begin{array}{l}1.9 \pm 0.8 \\
(1.0-2.8)\end{array}$ & $\begin{array}{c}9.7 \pm 3.5 \\
(6.4-13.8)\end{array}$ & $\begin{array}{l}451.1 \pm 145.3 \\
(251.3-599.6)\end{array}$ \\
\hline Russula sardonia (12) & $\begin{array}{l}13.8 \pm 9.7 \\
(4.7-36.1)\end{array}$ & $\begin{array}{l}3.5 \pm 2.0 \\
(1.4-8.2)\end{array}$ & $\begin{array}{l}35.8 \pm 22.7 \\
(11.1-72.6)\end{array}$ & $\begin{array}{l}1.2 \pm 0.5 \\
(0.4-2.1)\end{array}$ & $\begin{array}{c}7.8 \pm 6.9 \\
(1.4-23.8)\end{array}$ & $\begin{array}{l}115.5 \pm 48.1 \\
(56.7-208.0)\end{array}$ \\
\hline
\end{tabular}

Note: $(\mathrm{N})$ number of plots in which the species of mushrooms was collected, 27.0 mean \pm standard deviation, and (7.8-84.3) minimum and maximum value.

Table 4. Content of macroelements in the mushrooms of the study area.

\begin{tabular}{|c|c|c|c|c|c|c|c|c|}
\hline \multirow{2}{*}{ Element/Mushroom (N) } & $\mathbf{N}$ & C & $S$ & $\mathrm{Ca}$ & $\mathbf{K}$ & $\mathbf{P}$ & $\mathrm{Mg}$ & $\mathrm{Na}$ \\
\hline & \multicolumn{8}{|c|}{$\left(\mathrm{g} \cdot \mathrm{kg}^{-1}\right)$} \\
\hline \multirow{2}{*}{ Imleria badia (24) } & $59.6 \pm 0.7$ & $436.8 \pm 0.9$ & $5.3 \pm 0.1$ & $0.6 \pm 0.0$ & $38.2 \pm 0.5$ & $4.5 \pm 0.1$ & $0.7 \pm 0.0$ & $1.0 \pm 0.1$ \\
\hline & $(47.6-70.6)$ & $(421.8-448.6)$ & $(4.0-7.4)$ & $(0.2-1.5)$ & $(29.4-49.9)$ & $(2.8-7.0)$ & $(0.5-1.0)$ & $(0.3-3.3)$ \\
\hline Suillus luteus (6) & $\begin{array}{c}58.8 \pm 1.1 \\
(49.4-71.3)\end{array}$ & $\begin{array}{c}435.1 \pm 1.0 \\
(424.3-444.5)\end{array}$ & $\begin{array}{l}4.4 \pm 0.2 \\
(2.6-5.6)\end{array}$ & $\begin{array}{l}1.0 \pm 0.1 \\
(0.2-1.5)\end{array}$ & $\begin{array}{c}35.7 \pm 1.0 \\
(24.9-43.1)\end{array}$ & $\begin{array}{l}7.0 \pm 0.1 \\
(6.1-7.7)\end{array}$ & $\begin{array}{l}0.9 \pm 0.0 \\
(0.8-0.9)\end{array}$ & $\begin{array}{l}0.9 \pm 0.1 \\
(0.2-1.3)\end{array}$ \\
\hline Suillus grevillei (4) & $\begin{array}{c}43.3 \pm 0.3 \\
(40.9-45.7)\end{array}$ & $\begin{array}{c}439.9 \pm 0.6 \\
(435.7-444.1)\end{array}$ & $\begin{array}{l}2.3 \pm 0.0 \\
(2.0-2.5)\end{array}$ & $\begin{array}{l}0.5 \pm 0.0 \\
(0.4-0.6)\end{array}$ & $\begin{array}{c}24.2 \pm 0.3 \\
(22.2-26.2)\end{array}$ & $\begin{array}{l}5.9 \pm 0.1 \\
(5.5-6.4)\end{array}$ & $\begin{array}{l}0.7 \pm 0.0 \\
(0.7-0.8)\end{array}$ & $\begin{array}{l}0.7 \pm 0.0 \\
(0.5-0.8)\end{array}$ \\
\hline Suillus bovinus (4) & $\begin{array}{c}43.6 \pm 0.3 \\
(41.6-45.6)\end{array}$ & $\begin{array}{c}446.9 \pm 1.8 \\
(434.4-459.5)\end{array}$ & $\begin{array}{l}2.6 \pm 0.0 \\
(2.4-2.8)\end{array}$ & $\begin{array}{l}0.3 \pm 0.0 \\
(0.2-0.4)\end{array}$ & $\begin{array}{c}23.8 \pm 0.3 \\
(21.8-25.8)\end{array}$ & $\begin{array}{l}5.3 \pm 0.1 \\
(5.0-5.7)\end{array}$ & $\begin{array}{l}0.7 \pm 0.0 \\
(0.7-0.8)\end{array}$ & $\begin{array}{l}0.9 \pm 0.0 \\
(0.7-1.1)\end{array}$ \\
\hline Lactarius deliciosus (4) & $\begin{array}{c}48.2 \pm 0.2 \\
(47.2-49.3)\end{array}$ & $\begin{array}{c}443.8 \pm 1.2 \\
(435.5-452.1)\end{array}$ & $\begin{array}{l}2.2 \pm 0.0 \\
(2.1-2.3)\end{array}$ & $\begin{array}{l}0.5 \pm 0.0 \\
(0.3-0.7)\end{array}$ & $\begin{array}{c}38.8 \pm 1.0 \\
(31.4-46.1)\end{array}$ & $\begin{array}{l}5.8 \pm 0.1 \\
(5.0-6.7)\end{array}$ & $\begin{array}{l}0.8 \pm 0.0 \\
(0.7-0.9)\end{array}$ & $\begin{array}{l}0.2 \pm 0.0 \\
(0.2-0.3)\end{array}$ \\
\hline Lactarius helvus (18) & $\begin{array}{c}50.8 \pm 0.3 \\
(41.0-58.6)\end{array}$ & $\begin{array}{c}433.8 \pm 2.4 \\
(373.9-447.4)\end{array}$ & $\begin{array}{l}2.5 \pm 0.0 \\
(2.1-3.3)\end{array}$ & $\begin{array}{l}0.4 \pm 0.0 \\
(0.1-1.6)\end{array}$ & $\begin{array}{c}37.4 \pm 1.3 \\
(24.1-58.5) \\
\end{array}$ & $\begin{array}{l}6.6 \pm 0.2 \\
(4.2-9.1)\end{array}$ & $\begin{array}{l}0.9 \pm 0.0 \\
(0.5-1.4)\end{array}$ & $\begin{array}{l}0.3 \pm 0.0 \\
(0.1-0.9) \\
\end{array}$ \\
\hline Russula paludosa (6) & $\begin{array}{c}44.0 \pm 0.3 \\
(40.6-46.2)\end{array}$ & $\begin{array}{c}423.1 \pm 1.3 \\
(409.1-433.3)\end{array}$ & $\begin{array}{l}2.2 \pm 0.0 \\
(1.8-2.6)\end{array}$ & $\begin{array}{l}0.3 \pm 0.0 \\
(0.3-0.4)\end{array}$ & $\begin{array}{c}40.4 \pm 0.6 \\
(36.5-47.0)\end{array}$ & $\begin{array}{l}5.5 \pm 0.1 \\
(4.9-5.9)\end{array}$ & $\begin{array}{l}0.8 \pm 0.0 \\
(0.7-0.9)\end{array}$ & $\begin{array}{l}0.3 \pm 0.0 \\
(0.2-0.4)\end{array}$ \\
\hline Russula claroflava (4) & $\begin{array}{c}57.9 \pm 0.2 \\
(56.6-59.2)\end{array}$ & $\begin{array}{c}407.0 \pm 2.0 \\
(393.2-420.8)\end{array}$ & $\begin{array}{l}3.5 \pm 0.1 \\
(2.6-4.5)\end{array}$ & $\begin{array}{l}0.5 \pm 0.0 \\
(0.4-0.5)\end{array}$ & $\begin{array}{c}52.3 \pm 1.4 \\
(42.2-62.4)\end{array}$ & $\begin{array}{l}6.5 \pm 0.1 \\
(5.5-7.5)\end{array}$ & $\begin{array}{l}1.0 \pm 0.0 \\
(0.7-1.3)\end{array}$ & $\begin{array}{l}0.4 \pm 0.0 \\
(0.2-0.6)\end{array}$ \\
\hline Russula aeruginea (8) & $\begin{array}{c}45.1 \pm 1.1 \\
(35.8-57.5)\end{array}$ & $\begin{array}{c}423.0 \pm 1.2 \\
(406.7-432.6)\end{array}$ & $\begin{array}{l}2.6 \pm 0.0 \\
(2.3-3.2)\end{array}$ & $\begin{array}{l}0.4 \pm 0.0 \\
(0.3-0.5)\end{array}$ & $\begin{array}{c}35.4 \pm 0.8 \\
(26.2-46.3)\end{array}$ & $\begin{array}{l}4.3 \pm 0.1 \\
(3.2-6.4)\end{array}$ & $\begin{array}{l}0.6 \pm 0.0 \\
(0.4-0.8)\end{array}$ & $\begin{array}{l}0.6 \pm 0.0 \\
(0.4-0.8)\end{array}$ \\
\hline Russula sardonia (12) & $\begin{array}{c}46.2 \pm 0.1 \\
(36.4-62.7)\end{array}$ & $\begin{array}{c}433.9 \pm 1.4 \\
(405.9-455.2)\end{array}$ & $\begin{array}{l}2.4 \pm 0.1 \\
(1.7-3.5)\end{array}$ & $\begin{array}{l}0.3 \pm 0.0 \\
(0.2-0.6)\end{array}$ & $\begin{array}{c}37.8 \pm 0.8 \\
(30.8-54.0)\end{array}$ & $\begin{array}{l}5.1 \pm 0.1 \\
(3.4-7.5)\end{array}$ & $\begin{array}{l}0.7 \pm 0.0 \\
(0.5-1.0)\end{array}$ & $\begin{array}{l}0.4 \pm 0.0 \\
(0.1-0.9)\end{array}$ \\
\hline
\end{tabular}

Note: $(N)$ number of plots in which the species of mushrooms was collected, 59.6 mean \pm standard deviation, and (47.6-70.6) minimum and maximum value. 


\subsection{Concentrations of Heavy Metals in Families and Species of Forest Mushrooms}

The multivariate analysis of variance (MANOVA) showed differences in mushroom families simultaneously for measurements in all samples $\left(\mathrm{F}_{8.70}=3.054 ; p<0.01\right)$. The MANOVA showed that family Suillaceae should be qualified as the least sensitive to accumulation, while Boletaceae and Russulaceae, according to the multivariate analysis (CVA), are families with a similar sensitivity to heavy metal accumulation. Suillaceae differed significantly from Russulaceae and Boletaceae $(p<0.05)$. The observed differences in the accumulation of heavy metals by the tested mushroom families were presented by using CVA (Figure 2).

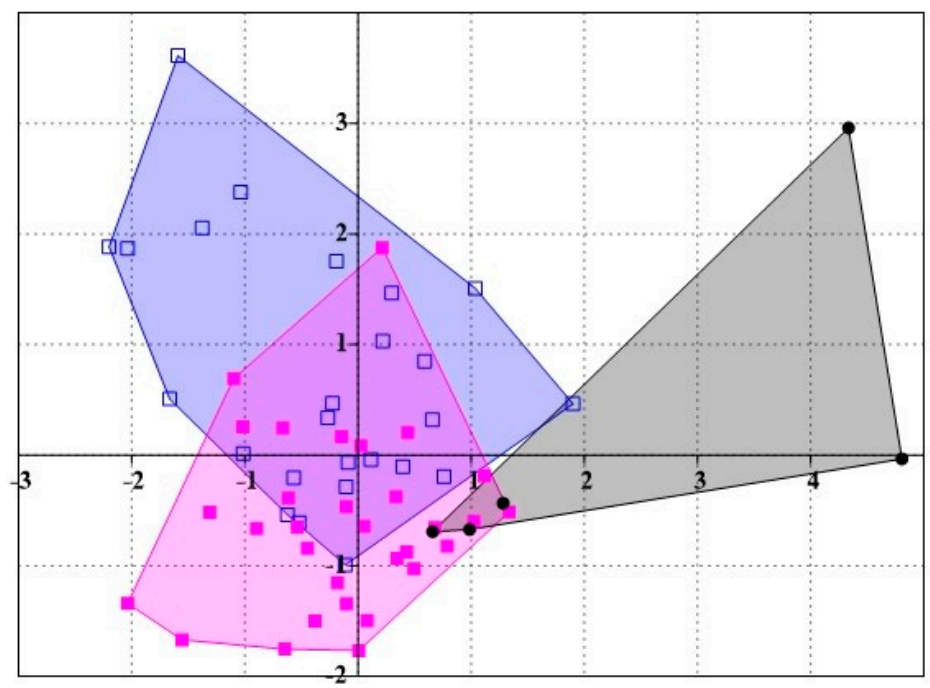

Figure 2. Canonical variate analysis (CVA) ordinance diagram showing the differences in the accumulation of heavy metals between the tested mushroom families. Open squares mean the Boletaceae family, painted squares mean Russulaceae, and black circles mean the Suillaceae family. Wilk's test $\lambda=0.46$. First axis explained $45.1 \%$ of variance and second axis explained $24.0 \%$ of variance.

Moreover, the CVA revealed that, of the examined mushroom species, those most frequently found in the area of study, Suillus bovinus and Russula aeruginea, accumulate $\mathrm{Zn}, \mathrm{Cd}$, and $\mathrm{Pb}$ to the greatest extent. Russula paludosa showed a lower accumulation capacity (Figure 3). Overall, the accumulation of $\mathrm{Zn}, \mathrm{Cd}$, and $\mathrm{Pb}$ was similar for the most abundant species.

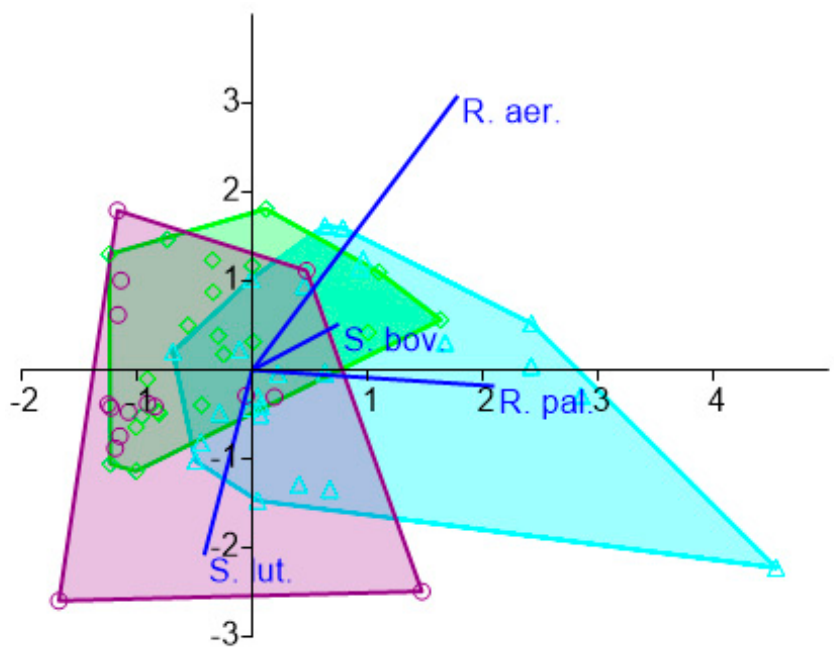

Figure 3. CVA ordinance diagram showing the differences in the accumulation of heavy metals between the most numerous mushroom species in the study area. Open circles mean $\mathrm{Zn}$, diamonds indicate $\mathrm{Cd}$, and triangles determine $\mathrm{Pb}$. Wilk's test $\lambda=0.67$. Note: S. bov-Suillus bovinus, R. aer.-Russula aeruginea, R. pal.-R. paludosa, S. lut.-S. luteus. 


\subsection{Heavy Metal Contents in Forest Mushrooms and Distance from the Main Emitter}

Autoregression according to the CAR equation showed a spatial relationship between the distance from the emitter and the content of heavy metals in the examined mushrooms $\left(R^{2}=0.46, R=0.66\right)$. This analysis showed that the contents of $\mathrm{Zn}, \mathrm{Cd}$, and $\mathrm{Pb}$ in mushrooms are significantly dependent on the distance to the main source of emission in the studied area (Table 5). The Response Variable Spatial Autoregressive Coefficient $(\rho)$ was 0.99 and indicated a good fit of the tested variables in the spatial arrangement.

Table 5. Results of the autoregressive model according to the equation in the covariance system, being a function of the matrix for adjacent estimated values.

\begin{tabular}{cccccc}
\hline Variable & OLS Coefficient & CAR Coefficient Standard & Standard Error & $\boldsymbol{t}$ & $\boldsymbol{p}$-Value \\
\hline Constant & 8.94 & 8.37 & 4.48 & 1.87 & 0.08 \\
\hline $\mathrm{Cd}$ & -0.04 & -0.04 & 0.05 & -0.68 & $<0.05$ \\
\hline $\mathrm{Cr}$ & 0.18 & 0.13 & 0.08 & 1.64 & 0.12 \\
\hline $\mathrm{Cu}$ & 0.05 & 0.04 & 0.02 & 1.95 & 0.07 \\
\hline $\mathrm{Ni}$ & -1.52 & -1.03 & 0.67 & -1.54 & 0.14 \\
\hline $\mathrm{Pb}$ & 0.071 & 0.05 & 0.034 & 1.58 & $p<0.01$ \\
\hline $\mathrm{Zn}$ & 0.0013 & 0.0014 & 0.004 & -0.02 & $p<0.05$ \\
\hline
\end{tabular}

Note: OLS Ordinary Least Square; CAR (conditional autoregressive model) Coefficient Standard-a parameter that estimates the response variables; $t$-test the Student's distribution.

The BCF indicated that, in the majority of the examined mushrooms, the highest bioconcentration was found for $\mathrm{Cd}$. This was especially evident in the case of Imleria badia, where the BCF between soil and mushrooms was 9.17 and that between litter and mushrooms was 1.77. The BCF was also significantly higher for $\mathrm{Cd}$ than for the other tested elements for such mushrooms as Suillus luteus, Lactarius helvus, Russula paludosa, and Russula sardonia. A lower BCF was noted for $\mathrm{Zn}$ and the lowest for $\mathrm{Pb}$ (Table 6).

Table 6. Bioconcentration factor (BCF) of heavy metals for individual mushroom species.

\begin{tabular}{lcccccc}
\hline \multirow{2}{*}{ Species } & \multicolumn{7}{c}{ Soil } & & Litter & \\
\cline { 2 - 7 } & Zn & Cd & Pb & Zn & Cd & Pb \\
\hline Imleria badia & 1.61 & 9.18 & 0.07 & 0.35 & 1.77 & 0.02 \\
\hline Suillus luteus & 1.26 & 4.18 & 0.03 & 0.27 & 0.81 & 0.01 \\
\hline Suillus grevillei & 0.81 & 1.39 & 0.01 & 0.81 & 0.27 & 0.01 \\
\hline Suillus bovinus & 0.68 & 1.48 & 0.02 & 0.15 & 0.29 & 0.01 \\
\hline Lactarius deliciosus & 0.99 & 1.21 & 0.04 & 0.21 & 0.23 & 0.01 \\
\hline Lactarius helvus & 1.27 & 3.90 & 0.04 & 0.27 & 0.75 & 0.01 \\
\hline Russula paludosa & 1.11 & 4.89 & 0.08 & 0.24 & 0.94 & 0.03 \\
\hline Russula claroflava & 2.60 & 3.78 & 0.06 & 0.56 & 0.73 & 0.02 \\
\hline Russula aeruginea & 4.45 & 3.43 & 0.05 & 0.96 & 0.66 & 0.02 \\
\hline Russula sardonia & 0.99 & 4.68 & 0.04 & 0.22 & 0.90 & 0.01 \\
\hline
\end{tabular}

Cadmium and zinc turned out to be the best predictors in the multidimensional analysis, for which factor loads were higher than 0.7. We recorded the positive relationship of $\mathrm{Zn}$ content with $\mathrm{S}$ and $\mathrm{Cd}$ 
content with $\mathrm{N}$, and the negative relationship of $\mathrm{Zn}$ content with $\mathrm{Ca}$, and $\mathrm{Cd}$ content with $\mathrm{S}$, TOC, and $\mathrm{Mg}$ (Table 7).

Table 7. Results of factor loads obtained on the basis of CCA analysis. Loads with high values $>0.7$ are bolded.

\begin{tabular}{ccccccc}
\hline Macroelement & Axis 1 & Axis 2 & Axis 3 & Axis 4 & Axis 5 & Axis 6 \\
\hline \multicolumn{7}{c}{ Zn } \\
\hline TOC & -0.17 & -0.34 & 0.25 & -0.17 & 0.22 & -0.03 \\
$\mathrm{~N}$ & 0.38 & 0.43 & 0.17 & 0.27 & 0.01 & -0.03 \\
$\mathrm{P}$ & -0.59 & 0.41 & -0.19 & -0.10 & -0.14 & 0.15 \\
$\mathrm{~S}$ & $\mathbf{0 . 8 9}$ & -0.51 & 0.14 & 0.04 & 0.02 & -0.14 \\
$\mathrm{Ca}$ & -0.52 & $\mathbf{- 0 . 8 1}$ & -0.35 & 0.13 & 0.06 & -0.07 \\
$\mathrm{Mg}$ & 0.60 & -0.65 & -0.18 & 0.18 & -0.20 & 0.20 \\
$\mathrm{~K}$ & -0.60 & 0.45 & -0.01 & -0.19 & 0.19 & 0.10 \\
$\mathrm{Na}$ & -0.54 & -0.32 & -0.14 & 0.002 & 0.09 & -0.17 \\
\hline & & & & $\mathrm{Cd}$ & & \\
$\mathrm{TOC}$ & 0.14 & $\mathbf{- 0 . 7 6}$ & 0.19 & -0.26 & 0.35 & -0.03 \\
$\mathrm{~N}$ & $\mathbf{0 . 7 1}$ & 0.26 & -0.15 & -0.00 & -0.05 & 0.21 \\
$\mathrm{P}$ & -0.11 & 0.69 & -0.09 & -0.02 & -0.02 & 0.03 \\
$\mathrm{~S}$ & 0.48 & $\mathbf{- 0 . 7 8}$ & -0.08 & -0.11 & 0.12 & 0.01 \\
$\mathrm{Ca}$ & -0.20 & 0.24 & -0.07 & -0.06 & -0.23 & -0.13 \\
$\mathrm{Mg}$ & 0.11 & $\mathbf{- 0 . 7 2}$ & 0.20 & -0.25 & 0.28 & 0.008 \\
$\mathrm{~K}$ & -0.13 & -0.61 & 0.21 & -0.34 & 0.34 & -0.05 \\
$\mathrm{Na}$ & -0.40 & 0.55 & -0.43 & -0.14 & -0.14 & -0.16 \\
\hline
\end{tabular}

\section{Discussion}

\subsection{Heavy Metal Accumulation in Forest Mushrooms}

The risk posed to many organisms by heavy metals consists mainly of their permanent entry into the food chain [35]. The toxicity level of heavy metals results not only from the degree of environmental contamination but also from their biochemical role in metabolic processes and from a high degree of absorption and excretion [36]. Most of the higher fungi have the ability to accumulate various metals and metalloids, including heavy metals, in their fruiting bodies [37]. Mushrooms take up both nutrients in mineral form and toxic metals from the soil and water, and, as such, they can be sources of those substances in human and animal nutrition [38]. Studies show that even small amounts of elements can be detected in the fruiting bodies of fungi $[9,39]$. Therefore, mushrooms are suitable for studies of heavy metal accumulation [40].

Individual species differ in terms of the degree of heavy metal accumulation in their fruiting bodies [41]. The highest contents of $\mathrm{Zn}$, at $60.6 \mathrm{mg} \cdot \mathrm{kg}^{-1}$, and $\mathrm{Mn}$, at $2.54 \mathrm{mg} \cdot \mathrm{kg}^{-1}$, reported in the literature were determined in Imleria badia obtained from uncontaminated sites [42]. The highest mean concentrations of $\mathrm{Pb}$, at 1.91 and $1.60 \mathrm{mg} \cdot \mathrm{kg}^{-1}$, were determined in the cap and stalk, respectively, of Macrolepiot procera. In our study, the $\mathrm{Pb}$ concentration in Imleria badia averaged $12 \mathrm{mg} \cdot \mathrm{kg}^{-1}$, with values exceeding $100 \mathrm{mg} \cdot \mathrm{kg}^{-1}$ on the most polluted sites (Table 3). The highest mean Cd concentrations reported in the literature were determined in the cap $\left(3.23 \mathrm{mg} \cdot \mathrm{kg}^{-1}\right)$ and stalk $\left(2.24 \mathrm{mg} \cdot \mathrm{kg}^{-1}\right) \mathrm{of}$ Agaricus campestris [31].

The spatial analysis in this study based on the spatial autoregressive model demonstrated that $\mathrm{Pb}$, $\mathrm{Cd}$, and $\mathrm{Zn}$ levels were related to the distance of study plots from the source of pollution (Table 5). The use of spatial autoregression models in the examination of heavy metal concentrations can also be applied to the assessment of air pollution [43]. The cluster analysis carried out on the accumulation of the studied metals showed a high phenotypic similarity of mushroom species belonging to the same genus and partial similarity of species with the same ecological affiliation [31]. These features are so significant that it is possible to use a specific mushroom species for monitoring of the environment [44]. 
In our study, CVA multidimensional analysis identified differences among fungal families in heavy metal accumulation (Figure 3).

\subsection{Mushrooms as Bioindicators of Contamination}

Mushrooms can play a role as bioindicators in the forest environment because they have a stronger ability to accumulate heavy metals, especially toxic ones such as $\mathrm{Pb}$ or $\mathrm{Cd}$, as compared to plants [45-48]. For example, Galerina vittiformis can serve as an indicator for soils with a high heavy metal content [49]. In this study, it was noted that, among the most common mushrooms in the study area, the accumulation of $\mathrm{Pb}, \mathrm{Cd}$, and $\mathrm{Zn}$ was particularly high in Russula aeruginea (Table 6). Another commonly occurring species in the study area, Imleria badia, is very useful for the biomonitoring of areas that are heavily contaminated with heavy metals and also seems to be eagerly collected for consumption purposes.

The heavy metal contents of the sampled mushroom species were related to the mineral composition of the sampled soils [35]. The contents of heavy metals in mushrooms may come from natural sources, e.g., from serpentine soils [50]. The concentrations of $\mathrm{Cd}$ and $\mathrm{Hg}$ in mushrooms may also be related to anthropogenic contamination from industrial, transportation, or agricultural activities [51]. A previous study of Amanita muscaria showed that this species is able to regulate the uptake and accumulation of $\mathrm{Ba}, \mathrm{Ca}, \mathrm{K}, \mathrm{Mg}, \mathrm{Na}$, and $\mathrm{Zn}$ contents in its cap [52]. Meanwhile, the dry-matter Fe content was mainly higher than the contents of $\mathrm{Cu}, \mathrm{Zn}, \mathrm{Mn}, \mathrm{Cd}, \mathrm{Cr}, \mathrm{Ni}$, and $\mathrm{Pb}$ in 14 different species of edible mushrooms collected from Yunnan Province, China [53]. In our study, the $\mathrm{N}$ content showed a relationship with $\mathrm{Cd}$ in the soil and litter, and to a lesser degree with $\mathrm{Zn}$ in the soil and litter.

\subsection{Metal Accumulation Rates}

The processes of absorption of heavy metals from the substrate and internal transport and accumulation in the fruiting body depend on many factors, including genetic factors, environmental factors such as climate and soil, and anthropogenic factors [11]. In a study by Liu et al. [13], health-risk indicators showed that mushrooms harvested in Yunnan Province (China) had higher As and Cd contents than $\mathrm{Pb}$ content. Important information is provided by the ratio of the concentration of a tested metal in a mushroom to the concentration in the substrate (soil/litter), i.e., the BCF. If the BCF exceeds 1 , that indicates a high accumulation potential of the mushroom species [54]. The highest mean value of $\mathrm{Pb}$ reported in the Boletaceae family was $0.70 \mathrm{mg} \cdot \mathrm{kg}^{-1}$, and the bioconcentration factor (BCF) for $\mathrm{Cd}$ in Boletus griseus reached 6.40 [55]. The bioconcentration factors suggested that mushrooms accumulate As and $\mathrm{Cd}$ faster than $\mathrm{Pb}$. The results of our study showed that the highest $\mathrm{BCF}$ for $\mathrm{Cd}$ was recorded for the following mushrooms: Imleria badia, Russula paludosa, Russula sardonia, and Suillus luteus in soil (Table 6). According to the calculated BCF values, all of the studied species are bioexclusors for lead and bioaccumulators for cadmium. For zinc, only Suillus grevillei and Suillus bovinus are bioexclusors, while Russula claroflava and Russula aeruginea are clear bioaccumulators.

\subsection{Food-Chain and Human-Health Assessment of Potential Risks}

Heavy metals pose a high potential risk to human health. The World Health Organization (WHO), in cooperation with the Food and Agriculture Organization of the United Nations (FAO) [56], has set the limits for the permissible intake of cadmium and lead in food at 7 and $15 \mu \mathrm{g}$ per kg of body weight per week, respectively $[13,57]$. These values per $60 \mathrm{~kg}$ body weight (average adult weight) are $0.42 \mathrm{mg}$ and $0.9 \mathrm{mg}$ per week, respectively. This means that the consumption of one kilogram of the Imleria badia mushrooms collected in this study (dry matter) would exhaust the limit for cadmium for an average of 64 weeks, and for more than 200 weeks in the most polluted areas. The same consumption would be equivalent to consuming the limit for lead for 13 weeks on average and 113 weeks in the most polluted sites. Comparing the $\mathrm{Pb}$ and $\mathrm{Cd}$ contents of the mushrooms with food product guidelines [58], we noted significant exceedances of the limit values $\left(0.3 \mathrm{mg} \cdot \mathrm{kg}^{-1}\right.$ for Pb and $1.0 \mathrm{mg} \cdot \mathrm{kg}^{-1}$ for $\mathrm{Cd}$ for 
fresh mass). Taking into account that the water content in mushrooms is in the order of approximately $90 \%$ [59,60], in the most polluted Imleria badia fruiting bodies, the $\mathrm{Pb}$ concentration exceeded the admissible value by about 30 -fold and the $\mathrm{Cd}$ concentration by about 10 -fold. Before Poland joined the European Union, the limit values for cadmium and lead were set at $0.15 \mathrm{mg} \cdot \mathrm{kg}^{-1}$ (cadmium) and $0.30 \mathrm{mg} \cdot \mathrm{kg}^{-1}$ (lead) for fresh mass [61], and these values were exceeded on all study plots and in all species of collected mushrooms.

\section{Conclusions}

This study showed that, in areas heavily contaminated with heavy metals, mushrooms of the family Suillaceae accumulate fewer heavy metals when compared to mushrooms of the families Boletaceae and Russulaceae. A spatial dependence relationship was shown between the distance from the main metallic pollutant emitter in the studied area and the content of heavy metals in the mushrooms. The analyzed BCF values indicated that, in the majority of the examined mushrooms, the highest level of bioaccumulation was found for $\mathrm{Cd}$. This was particularly evident in the case of Imleria badia. The study also showed positive the relationship of $\mathrm{Zn}$ content with $\mathrm{S}$ and $\mathrm{Cd}$ content with $\mathrm{N}$, and the negative relationship of $\mathrm{Zn}$ content with $\mathrm{Ca}$, and $\mathrm{Cd}$ content with $\mathrm{S}, \mathrm{TOC}$, and $\mathrm{Mg}$. High concentrations of heavy metals probably impede the intake of macroelements. The determined contents of heavy metals for mushrooms harvested in areas that are heavily contaminated with heavy metals indicate a high potential health risk if the mushrooms are consumed.

Author Contributions: M.P. (Marek Pająk) and M.P. (Marcin Pietrzykowski) conceived and designed the research. M.P. (Marek Pająk) and M.J. conducted experiments, M.P. (Marek Pająk), M.G., M.J., W.H., K.O. and M.P. (Marcin Pietrzykowski) analyzed data and wrote the manuscript. M.P. (Marek Pajak), M.G., M.J., W.H., K.O. and M.P. (Marcin Pietrzykowski) revised the manuscript. All authors have read and agreed to the published version of the manuscript.

Funding: The study was financed from a subvention from the Ministry of Science and Higher Education for the University of Agriculture, in Krakow, in 2020. The statistical analysis was made based on the knowledge and skills achieved during the training, organized as part of the project Integrated Program of the University of Agriculture in Krakow, which is co-financed by the European Union (POWR.03.05.00-00-z222/17).

Conflicts of Interest: The authors declare no conflict of interest.

\section{References}

1. Kalač, P.; Svoboda, L. Review of trace element concentrations in edible mushrooms. Food Chem. 2000, 69, 273-281. [CrossRef]

2. Zheng, X.; Suwandi, J.; Fuller, J.; Doromla, A.; Ng, K. Antioxidant capacity and mineral contents of edible wild Australian mushrooms. Food Sci. Technol. Int. 2012, 18, 367-379. [CrossRef] [PubMed]

3. Kalač, P. A review of chemical composition and nutritional value of wildgrowing and cultivated mushrooms. J. Sci. Food Agric. 2013, 93, 209-218. [CrossRef] [PubMed]

4. Wang, X.; Zhang, J.; Wu, L.; Zhao, Y.; Li, T.; Li, J.; Wang, Y.; Liu, H. A mini-review of chemical composition and nutritional value of edible wild-grown mushroom from China. Food Chem. 2014, 151, 279-285. [CrossRef]

5. Falandysz, J.; Borovička, J. Macro and trace mineral constituents and radionuclides in mushrooms-health benefits and risks. Appl. Microbiol. Biotechnol. 2013, 97, 477-501. [CrossRef]

6. Ma, L.S.; Chen, H.X.; Zhu, W.C.; Wang, Z.S. Effect of different drying methods on physicochemical properties and antioxidant activities of polysaccharides extracted from mushroom Inonotus obliquus. Food Res. Int. 2013, 50, 633-640. [CrossRef]

7. Vamanu, E.; Nita, S. Antioxidant capacity and the correlation with major phenolic compounds, anthocyanin, and tocopherol content in various extracts from the wild edible Boletus edulis mushroom. BioMed Res. Int. 2013, 2013, 313905. [CrossRef]

8. Türkmen, M.; Budur, D. Heavy metal contaminations in edible wild mushroom species from Turkey's Black Sea region. Food Chem. 2018, 254, 256-259. [CrossRef] 
9. Kokkoris, V.; Massas, J.; Polemis, E.; Koutrotsios, G.; Zervakis, G.I. Accumulation of heavy metals by wild edible mushrooms with respect to soil substrates in the Athens metropolitan area (Greece). Sci. Total Environ. 2019, 85, 280-296. [CrossRef]

10. Kalač, P.; Nižnanská, M.; Bevilaqua, D.; Stašková, I. Concentrations of mercury, copper, cadmium and lead in fruiting bodies of edible mushrooms in the vicinity of a mercury smelter and a copper smelter. Sci. Total Environ. 1996, 177, 251-258. [CrossRef]

11. Falandysz, J.; Kunito, T.; Kubota, R.; Bielawski, L.; Mazur, A.; Falandysz, J.J.; Tanabe, S. Selected elements in Brown Birch Scaber Stalk Leccinum scabrum. J. Environ. Sci. Health 2007, 42, 2081-2088. [CrossRef] [PubMed]

12. Falandysz, J.; Frankowska, A.; Jarzynska, G.; Dryzalowska, A.; Kojta, K.A.; Zhang, D. Survey on composition and bioconcentration potential of 12 metalic elements in King Bolete (Boletus edulis) mushroom that emerged at 11 spatially distant sites. J. Environ. Sci. Health 2011, 46, 231-246. [CrossRef] [PubMed]

13. Liu, B.; Huang, Q.; Cai, H.; Guo, X.; Wang, T.; Gui, M. Study of heavy metal concentrations in wild edible mushrooms in Yunnan Province, China. Food Chem. 2015, 188, 294-300. [CrossRef] [PubMed]

14. Krzaklewski, W.; Pietrzykowski, M. Selected physico-chemical properties of zinc and lead ore tailings and their biological stabilisation. Water Air Soil Pollut. 2002, 141, 125-142. [CrossRef]

15. Krzaklewski, W.; Barszcz, J.; Małek, S.; Kozioł, K.; Pietrzykowski, M. Contamination of forest soils in the vicinity of the sedimentation pond after zinc and lead ore flotation (in the region of Olkusz, southern Poland). Water Air Soil Pollut. 2004, 159, 151-164. [CrossRef]

16. Pietrzykowski, M.; Socha, J.; van Doorn, N.S. Linking heavy metal bioavailability (Cd, $\mathrm{Cu}, \mathrm{Zn}$ and $\mathrm{Pb})$ in Scots pine needles to soil properties in reclaimed mine areas. Sci. Total Environ. 2014, 470-471, 501-510. [CrossRef]

17. Pajak, M.; Halecki, W.; Gasiorek, M. Accumulative response of Scots pine (Pinus sylvestris L.) and silver birch (Betula pendula Roth) to heavy metals enhanced by $\mathrm{Pb}-\mathrm{Zn}$ ore mining and processing plants: Explicitly spatial considerations of ordinary kriging based on a GIS approach. Chemosphere 2017, 168, 851-859. [CrossRef]

18. Pająk, M.; Błońska, E.; Szostak, M.; Gąsiorek, M.; Pietrzykowski, M.; Urban, O.; Derbis, P. Restoration of vegetation in relation to soil properties of spoil heap heavily contaminated with heavy metals. Water Air Soil Pollut. 2018, 229, 392. [CrossRef]

19. Ullrich, S.M.; Ramsey, M.H.; Helios-Rybicka, E. Total and exchangeable concentrations of heavy metals in soils near Bytom, an area of $\mathrm{Pb} / \mathrm{Zn}$ mining and smelting in Upper Silesia, Poland. Appl. Geochem. 1999, 14, 187-196. [CrossRef]

20. Pająk, M.; Jasik, M. Heavy metal ( $\mathrm{Zn}, \mathrm{Pb}, \mathrm{Cd})$ concentration in soil and moss (Pleurozium schreberii) in the Brynica district, southern Poland. iFor.-Biogeosci. For. 2011, 4, 176-180. [CrossRef]

21. Pająk, M.; Jasik, M. Zawartość cynku, kadmu i ołowiu w owocach borówki czarnej (Vaccinium myrtillus L.) rosnącej w lasach Nadleśnictwa Świerklaniec. Sylwan 2012, 156, 233-240. (In Polish)

22. Chrastný, V.; Vaněk, A.; Teper, L.; Cabala, J.; Procházka, J.; Pechar, L.; Drahota, P.; Penížek, V.; Komárek, M.; Novák, M. Geochemical position of $\mathrm{Pb}, \mathrm{Zn}$ and $\mathrm{Cd}$ in soils near the Olkusz mine/smelter, South Poland: Effects of land use, type of contamination and distance from pollution source. Environ. Monit. Assess. 2012, 184, 2517-2536. [CrossRef] [PubMed]

23. Gruszecka, A.M.; Wdowin, M. Characteristics and distribution of analyzed metals in soil profiles in the vicinity of a postflotation waste site in the Bukowno region, Poland. Environ. Monit. Assess. 2013, 185, 8157-8168. [CrossRef] [PubMed]

24. Ciarkowska, K.; Sołek-Podwika, K.; Wieczorek, J. Enzyme activity as an indicator of soil-rehabilitation processes at a zinc and lead ore mining and processing area. J. Environ. Manag. 2014, 132, 250-256. [CrossRef] [PubMed]

25. Pająk, M.; Cygan, A.; Bilański, P.; Kołodziej, Z. Growth and development of the Scots pine (Pinus sylvestris L.) in forest environments strongly polluted with heavy metals. J. Environ. Prot. Ecol. 2015, 16, 620-629.

26. Pająk, M.; Błońska, E.; Frąc, M.; Oszust, K. Functional Diversity and Microbial Activity of Forest Soils that Are Heavily Contaminated by Lead and Zinc. Water Air Soil Pollut. 2016, 227, 348. [CrossRef]

27. IUSS Working Group WRB. World Reference Base for Soil Resources 2006, First Update 2007; World Soil Resources Reports No. 103; Technical Report for FAO: Rome, Italy, 2007.

28. Forest Management Plan 2003-2012. Olkusz Forest District (Paper Version in Polish). Available online: https://www.krnap.cz/pl/plan-urzadzenia-lasu-pul-/ (accessed on 23 November 2020).

29. Hammer, Ø.; Harper, D.A.T.; Ryan, P.D. PAST: Paleontological statistics software package for education and data analysis. Palaeontol. Electron. 2001, 4, 9. 
30. Rangel, T.F.; Diniz-Filho, J.A.F.; Bini, L.M. SAM: A comprehensive application for Spatial Analysis in Macroecology. Ecography 2010, 33, 46-50. [CrossRef]

31. Širić, I.; Humar, M.; Kasap, A.; Kos, I.; Mioč, B.; Pohleven, F. Heavy metal bioaccumulation by wild edible saprophytic and ectomycorrhizal mushrooms. Environ. Sci. Pollut. Res. 2016, 23, 18239-18252. [CrossRef]

32. Mackay, D.; Celsie, A.K.; Powell, D.E.; Parnis, J.M. Bioconcentration, bioaccumulation, biomagnification and trophic magnification: A modelling perspective. Environ. Sci. Process. Impacts 2018, 20, 72-85. [CrossRef]

33. Shahabivand, S.; Tayebnia, V.; Aliloo, A.A. Impact of endophyte fungus Serendipita indica on fungus-assisted phyto-stabilization and performance of Carthamus tinctorius in a lead polluted soil. J. Plant Res. 2019, 31, 812-824.

34. Lepš, J.; Šmilauer, P. Multivariate Analysis of Ecological Data Using CANOCO, 2nd ed.; Cambridge University Press: New York, NY, USA, 2014. [CrossRef]

35. Wang, X.; Liu, H.; Zhang, J.; Li, T.; Wang, Y. Evaluation of heavy metal concentrations of edible wild-grown mushrooms from China. J. Environ. Sci. Health 2017, 52, 178-183. [CrossRef] [PubMed]

36. Szynkowska, M.I.; Pawlaczyk, A.; Albinska, J.; Paryjczak, T. Comparison of accumulation ability of toxicologically important metals in caps and stalks in chosen mushrooms. Pol. J. Chem. 2008, 82, 313-319.

37. Sarikurkcu, C.; Copur, M.; Yildiz, D.; Akata, I. Metal concentration of wild edible mushrooms in Soguksu National Park in Turkey. Food Chem. 2011, 128, 731-734. [CrossRef]

38. Chen, X.H.; Zhou, H.B.; Qiu, G.Z. Analysis of several heavy metals in wild edible mushrooms from regions of China. Bull. Environ. Contam. Toxicol. 2009, 83, 280-285. [CrossRef]

39. Radulescu, C.; Stihi, C.; Busuioc, G.; Gheboianu, A.I.; Popescu, I.V. Studies concerning heavy metals bioaccumulation of wild edible mushrooms from industrial area by using spectrometric techniques. Bull. Environ. Contam. Toxicol. 2010, 84, 641-646. [CrossRef]

40. Poursaeid, N.; Azadbakht, A.; Balali, G.R. Improvement of zinc bioaccumulation and biomass yield in the mycelia and fruiting bodies of Pleurotus florida cultured on liquid media. Appl. Biochem. Biotechnol. 2015, 175, 3387-3396. [CrossRef]

41. Kojta, A.K.; Gucia, M.; Jarzynska, G.; Lewandowska, M.; Zakrzewska, A.; Falandysz, J.; Zhang, D. Phosphorus and certain metals in parasol mushrooms (Macrolepiota procera) and soils from the Augustowska forest and Ełk region in north-eastern Poland. Fresenius Environ. Bull. 2011, 20, 3044-3052.

42. Kuziemska, B.; Wysokiński, A.; Jaremko, D.; Popek, M.; Kożuchowska, M. The content of some heavy metals in edible mushrooms. Ecol. Eng. 2018, 19, 66-70. [CrossRef]

43. Lee, D.; Rushworth, A.; Sahu, S.K. A Bayesian localized conditional autoregressive model for estimating the health effects of air pollution. Biometrics 2014, 70, 419-429. [CrossRef]

44. Campos, J.A.; Tereja, N.A. Elements bioaccumulation in Sporocarps of fungi collected from quartzite acidic soils. Biol. Trace Elem. Res. 2011, 143, 540-554. [CrossRef] [PubMed]

45. Alonso, J.; Garcia, M.A.; Perez-Lopez, M.; Melgar, M.J. The concentrations and bioconcentration factors of copper and zinc in edible mushrooms. Arch. Environ. Contam. Toxicol. 2003, 44, 180-188. [CrossRef] [PubMed]

46. Garcia, M.A.; Alonso, J.; Melgar, M.J. Lead in edible mushrooms. Levels and bioconcentration factors. J. Hazard. Mater. 2009, 167, 777-783. [CrossRef] [PubMed]

47. Brzostowski, A.; Falandysz, J.; Jarzyńska, G.; Zhang, D. Bioconcentration potential of metallic elements by Poison Pax (Paxillus involutus) mushroom. J. Environ. Sci. Health 2011, 46, 378-393. [CrossRef]

48. Jarzyńska, G.; Gucia, M.; Kojta, A.K.; Rezulak, K.; Falandysz, J. Profile of trace elements in Parasol Mushroom (Macrolepiota procera) from Tucholskie Forest. J. Environ. Sci. Health 2011, 46, 741-751. [CrossRef]

49. Damodaran, D.; Shetty, K.V.; Balakrishnan, M.R. Interaction of Heavy Metals in Multimetal Biosorption by Galerina vittiformis from Soil. Bioremediat. J. 2015, 1, 56-68. [CrossRef]

50. Aloupi, M.; Koutrotsios, G.; Koulousaris, M.; Kalogeropoulos, N. Trace metal contents in wild edible mushrooms growing on serpentine and vulcanic soils on the island of Levos, Greece. Ecotoxicol. Environ. Saf. 2012, 78, 184-194. [CrossRef]

51. Gucia, M.; Jarzyńska, G.; Rafał, E.; Roszak, M.; Kojta, A.K.; Osiej, I.; Falandysz, J. Multivariate analysis of mineral constituents of edible Parasol Mushroom (Macrolepiota procera) and soils beneath fruiting bodies collected from Northern Poland. Environ. Sci. Pollut. Res. 2011, 19, 416-431. [CrossRef]

52. Lipka, K.; Falandysz, J. Accumulation of metallic elements by Amanita muscaria from rural lowland and industrial upland regions. J. Environ. Sci. Health 2017, 52, 184-190. [CrossRef] 
53. Zhu, F.; Qu, L.; Fan, W.; Qiao, M.; Hao, H.; Wang, X. Assessment of heavy metals in some wild edible mushrooms collected from Yunnan Province, China. Environ. Monit. Assess. 2011, 79, 191-199. [CrossRef]

54. Scragg, A. Environmental Biotechnology, 2nd ed.; Oxford University Press: Oxford, UK, 2006.

55. Sun, L.; Chang, W.; Bao, C.; Zhuang, Y. Metal Contents, Bioaccumulation, and Health Risk Assessment in Wild Edible Boletaceae Mushrooms. J. Food Sci. 2017, 82, 1500-1508. [CrossRef] [PubMed]

56. JECFA/73/SC. Joint 2010. FAO/WHO Expert Committee on Food Additives. In Proceedings of the Seventy-third Meeting, Geneva, Switzerland, 8-17 June 2010. Available online: http://www.fao.org/ ag/agn/agns/jecfa_index_en.asp (accessed on 23 November 2020).

57. Fang, Y.; Sun, X.; Yang, W.; Ma, N.; Xin, Z.; Fu, J.; Liu, X.; Liu, M.; Mariga, A.M.; Zhu, X.; et al. Concentrations and health risks of lead, cadmium, arsenic, and mercury in rice and edible mushrooms in China. Food Chem. 2014, 147, 147-151. [CrossRef] [PubMed]

58. EU 2008. Commission Regulation (EC) No 629/2008 of 2 July 2008 amending Regulation (EC) No 1881/2006 Setting Maximum Levels for Certain Contaminants in Foodstuffs, Official Journal of the European Union. (372008L173/6-9). Available online: https://eur-lex.europa.eu/legal-content/EN/TXT/PDF/?uri=CELEX: 32008R0629 (accessed on 23 November 2020).

59. Chudzyński, K.; Falandysz, J. Multivariate analysis of elements content of Larch Bolete (Suillus grevillei) mushroom. Chemosphere 2008, 73, 1230-1239. [CrossRef] [PubMed]

60. Palazzolo, E.; Letizia Gargano, M.; Venturella, G. The nutritional composition of selected wild edible mushrooms from Sicily (southern Italy). Int. J. Food Sci. Nutr. 2012, 63, 79-83. [CrossRef]

61. Regulation of the Polish Minister of Health (January 13th, 2003) about the Maximum Levels of Chemical and Biological Contaminants That May be Present in Food, Food Ingredients, Permitted Additives, Processing Aids or on the Surface of Food (Dz.U. 2003, Position 326) (In Polish). Available online: http://isap.sejm.gov.pl/isap. nsf/DocDetails.xsp?id=WDU20030370326 (accessed on 23 November 2020).

Publisher's Note: MDPI stays neutral with regard to jurisdictional claims in published maps and institutional affiliations.

(C) 2020 by the authors. Licensee MDPI, Basel, Switzerland. This article is an open access article distributed under the terms and conditions of the Creative Commons Attribution (CC BY) license (http://creativecommons.org/licenses/by/4.0/). 